Palestine Exploration Quarterly

\title{
Notes on the Old Hebrew Calendar-Inscription from Gezer
}

\section{Gustaf Dalman}

To cite this article: Gustaf Dalman (1909) Notes on the Old Hebrew Calendar-Inscription from Gezer, Palestine Exploration Quarterly, 41:2, 118-119, DOI: 10.1179/peq.1909.41.2.118

To link to this article: http://dx.doi.org/10.1179/peq.1909.41.2.118

巴nublished online: 20 Nov 2013.

Submit your article to this journal $\sqsubset$

Џll Article views: 7

Q View related articles $\sqsubset$ 
of Western Asia, with slight variations in accordance with the conditions of the country. Agricultural names of the months are no doubt the earliest. The Gezer calendar is most probably much older than the inscription itself. To this fact, too, the Babylonian parallels seem to point.

Further investigations in this direction may throw more light on the Gezer tablet as well as on the Semitic calendar in general.

Jews' College, London, March 7th, 1909.

\section{NOTES ON THE OLD HEBREW CALENDAR-INSCRIPTION FROM GEZER.}

\section{By Professor Gustaf Dalman, Jerusalem.}

TAKIng the reading of Prof. Lidzbarski as satisfactory, I make the following remarks :-

1. Asiph is not fruit-harvest, but means in-gathering. In the month Tishri (October) the fruit.harvest finishes, and the fruit is 'gathered to the house.

2. The month of sowing is either November or December. Perhaps December is meant, then the sign between asiph and yerah might mean that one month is wanting.

3. Läkish cannot mean "aftergrass" at this time of the year. It is either the "late sowing," which begins in February, or the preparing of the fields for "the summer seed," more probably the former. Then February was meant, and the sign before this month could again mean that one month is wanting.

4. Indeed flax could not be cut, but it may have been pulled out with the help of a hoe. According to the Mishna (Peah IV, 4) the hoe:was in frequent use at the "pulling out" in harvest. The hoe is here called kardom, which was in use both for hewing wood and digging, like the kaddum of the Arabs. I should read ' ${ }^{a} s \bar{a} d$ and pishta. March must be the month indicated.

5. The month of the barley-harvest, without doubt, is here April.

6. The "harvest of all" may mean the time when, in all parts of the country, harvest is going on. This is true for May. 
7. Zämĩr can, neither here nor in Cant. ii, 12, mean the first pruning of vine, which is done in March, but the second pruning in June or July. Here June is meant. The knife or sickle used in pruning is still called zäburra in some parts of Palestine, which reminds one of the Hebrew zāminr.

8. The month of fruit-harvest will be July. In the calendar of the Beduin, the three months of $k \bar{e} d$ are June, July, and August. Then July may be called the month of fruit-harvest par excellence.

Now August and September are wanting to make the year complete. The $N$ and $ב$ at the margin may be a hint of these two months.

I find it most probable that the dubious sign before $\bar{a} s \bar{p} p h, z e r a$, $l \bar{a} k \bar{i} s h, k \bar{l} l$, and $z \bar{a} m \bar{\imath} r$ is $\vec{\sim}$, as the article is very necessary in these cases. The article is not used before she'orim, as it is never done in the designation of barley-harvest and wheat-harvest in Biblical Hebrew, evidently because it was a very common expression. The same will be true about yerach kayis without the article, although we cannot prove it.

JERUSALEM, January 22nd, 1909.

[Note.-Too late for more than mention, we have received a proof of an Article by the Rev. Father H. Vincent, written for the Revue Biblique, on the subject of the Hebrew "Calendar" Tablet, which will appear in the next issue of the Revue, and of which we hope to give an Abstract.]

\section{NOTES FROM DAMASCUS AND THE ANTI-LIBANUS.}

By the Rev. J. E. Hanauer.

Damascus, its scenery, surroundings, people, bazaars and mosques, have been so often described by travellers and in guide-books that it seems superfluous to attempt to write any more about them. My apology for submitting the following notes is, that though they refer to matters of very trifling significance and importance, yet they were things new to me who had never, previous to March, 1908, visited Damascus, and they struck me by their novelty and quaintness in a manner in which they did not seem to have awakened the attention of others who did not, or perhaps from a lack of a knowledge of Arabic could not notice them. 